\title{
Interjú Csongor Barnabással
}

\section{Csongor Barnabás}

Csongor Barnabás (1923-2018) a Pázmány Péter Tudományegyetemen (később ELTE) magyar-olasz szakos volt, miközben Ligeti Lajosnál tanult kínai, török és mongol filológiát. 1948-tól az ELTE Kelet-ázsiai Tanszékén tanársegéd, majd adjunktus (1950) és docens (1962) lett. 1963 és 1983 között a tanszék vezetöje volt, ahol 1991-től nyugdíjasként is sokáig tanított még.

Sinológiai munkássága alapvetően két részre osztható, és mindkét területen kiemelkedőt alkotott:

1. Történeti nyelvészeti kutatásaiban különösen nagy figyelemmel fordult a nem kínai (ujgur, tibeti, bráhmi) írású emlékekhez, és e korábban negligált forrásokról kimutatta, hogy relevánsak a középkori kínai kiejtés rekonstruálásában. Legfontosabb ilyen jellegü írásai a következők: „Chinese in the Uighur Script of the T'ang-period” Acta Orientalia Hung. II (1952) 73-122; „Some Chinese Texts in Tibetan Script from Tun-huang" Acta Orientalia Hung. X (1960) 97-140; „A Chinese Buddhist Text in Brahmi Script” Unicorn (Chi-lin) (1972) 36-77.

2. Kiemelkedő stilisztikai érzékét egykori magyar szakosként a müfordítás területén is kamatoztatta. Ilyen irányú érdeklödése már az '50-es években megnyilvánul, amikor Tang-kori költők (Li Taibo, Bo Juyi, Du Fu) verseinek válogatását és nyersfordítását végzi, 1961-ben pedig megjelenik első regényfordítása (Vizparti történet I-II). 1967-ben Tőkei Ferenccel közösen adják ki a Klasszikus kínai költő́k (I-II.) antológiát, majd 1969-ben egy újabb nagyívü regényfordítást (Nyugati utazás avagy a Majomkirály története I-II.) jelentetett meg. A fordítások mellett elméleti jellegü tanulmányokat is publikált a kínai regényről. 


\section{Bevezetés írta: Galambos Imre}

Az itt közölt interjúhoz az apropót eredetileg Shih Chi-yu professzor, a National Taiwan University tanárának felkérése szolgáltatta, aki éppen egy, az európai sinológia történet felölelő „oral history” projekt keretén belül keresett magyarországi kapcsolatot. Javasoltam, hogy korára és jelentőségére tekintettel Csongor Barnabás professzor kellene legyen az első interjúalany. Mivel jómagam is Tanár úr tanítványa voltam valamikor, az interjút szívesen vállaltam magamra. Ugyanazon látogatásom alkalmával interjút készítettem Tanár úr feleségével, Dr. Ferenczy Máriával is. Magukra az interjúkra három alkalommal került sor 2016 telén, amelyből az első kettő Csongor tanár úrral, míg a harmadik Ferenczy tanárnővel készült. Ebben a számban a Csongor beszélgetés kerül közlésre.

Elsősorban Tanár úr egészségügyi állapotának volt köszönhető, hogy míg az interjú részletesebben foglalkozik életének korai szakaszával, a szük értelemben vett szakmai rész rövidebbre sikerült, mert Tanár úr kifáradt és pihennie kellett. Látszott, hogy felkészült a találkozásra és átgondolt egy sor dolgot, amit el akart mondani, de később már sokkal spontánabb volt a beszélgetés. Ezért is áll két részből az interjú, s érdemes lett volna tovább folytatni néhány héttel később, de akkoriban sajnos nem volt módom ennyire gyakran Budapestre járni.

Szólnék pár szót személyes kapcsolatomról is Tanár úrral. Két évet jártam az ELTE Kínai Tanszékére 1992 és 1994 között, s ezalatt az idő alatt rendszeresen látogattam Tanár úr óráit és szemináriumait. Ezek zöme szövegolvasásból állt, de amíg átrágtuk magunkat a Lunyu 論語, a Sanzijing 三字經 vagy a Shuihu zhuan 水滸傳 eredeti szövegén, addig nagy mennyiségben kaptunk háttérinformációt minden más kínai dologról is. Így a szövegek fordítása bizonyos szempontból csak ürügy volt arra, hogy Kínáról és a klasszikus kínai történelemröl tanulhassunk.

Emlékezetes élmény maradt, hogy egyszer néhányan megkértük Tanár urat, hogy fakultatív foglalkozás keretében olvassunk közösen a Zhuangzi 莊子 belső fejezeteiből. Ezt azért kértük, mert az órán mindig csak a konfuciánus tananyag szövegeit olvastuk, amelyek akkoriban száraznak és unalmasnak tűntek. Ezzel szemben a Zhuangzi egy színes és izgalmas világot jelentett, amelyet valamilyen oknál fogva rendszerint elkerültünk az órákon. Tanár úr beleegyezett, hogy persze, szívesen olvas velünk Zhuangzi-t. Mégis, 
amikor először összegyültünk az Izabella utcai tanáriban, azzal kezdte, ahhoz, hogy rendesen megértsük a Zhuangzi világát, muszáj lesz a Zuozhuan 左傳 nevü krónikával kezdenünk. A Zuozhuan persze semmivel sem volt jobb, mint a többi konfuciánus szöveg, amelyet addig olvastunk, de most már nem menekülhettünk, és legalábbis néhány alkalommal ott kellett ülnünk a szabadidőnkben és olvasni a száraz és tömör történelmi prózát.

Egy másik különös emlékem, hogy egy késő délutáni óra után egy darabig elkísértem a Tanár urat és sokáig beszélgettünk szövegekről és más izgalmas dolgokról. Aztán búcsúzáskor rámnézett és azt mondta: „Imre, ha maga jó sinológus akar lenni, akkor ne nősüljön meg!" Ebből az utolsó három szót tagolva hangsúlyozta. Persze ő is nős volt és az intelme engem sem tartott vissza a házasodástól.

Talán mert eredetileg szakterületemnek az ókori Kínát választottam, viszonylag sok közös témánk volt. Abban is különbözött többi tanáromtól a tanszéken, hogy ő elsősorban szakmai dolgokról szeretett társalogni és az anekdota jellegü személyes élmények ritkábban kerültek elö. Külön élmény volt látni, hogy enciklopédikus tudásának köszönhetően a kínai történelem bármelyik korszakához és szinte bármilyen témához hozzá tudott szólni és hasznos tanácsot adni. Ugyanakkor rendkívül kritikus is volt és néha úgy tünt, hogy semmi sem volt elég pontos vagy alapos számára. Tulajdonképpen saját kutatási módszere is ehhez kapcsolódott, mert - mint ahogy ezt többször emlegette - neki magyarországi sinológusként nem volt alkalma eredeti szövegleleteket feldolgozni és kiadni, hanem helyette figyelmesen végigrágta magát mások ilyen jellegü munkáin és az azokban talált hibákat dolgozta fel és írta meg.

Mire elvégeztem tanulmányaimat és elhelyezkedtem, Tanár úr már nyugdíjba vonult, és így nagyjából egy vagy kétévente ellátogattam Hernád utcai otthonukba tiszteletemet tenni. Ilyenkor mindig leültettek és másfél-két órán keresztül beszélgettünk a legkülönbözőbb szakmai dolgokról. Valójában sajnálom, hogy az akkori beszélgetéseink nem kerültek rögzítésre, mert rendkívül tanulságosak és izgalmasak voltak, és mindig tanultam egy sor teljesen új dolgot.

A találkozásaink során sokszor beszélt az éppen folyamatban lévő fordításairól is. Már 2000 környékén sokat beszélt a Zhuangzi (Chuang-ce) fordításáról, amelyet akkoriban készített. Már készen volt, de még mindig javítgatta, simítgatta. Egyszer kihozta az egész kéziratot és azt mondta: „Na Imre, nézze, itt van az egész. Megmutatom magának, hogy megvan. Majd elmondhatja, 
hogy maga látta." De aztán valószínüleg sosem lett vele teljesen elégedett, mert máig nem jelent meg. Néhány évvel később áttért a Jinpingmei 金瓶梅 (Szép asszonyok egy gazdag házban) fordítására és sokat beszélt erről is. Azt mondta, hogy most kezdte igazán élvezni a kínai nyelvet. Ezzel is nagyjából készen volt már, de még mindig folytatta a munkát. Nyilván nemcsak másokkal, hanem önmagával is szigorú volt.

\section{Első beszélgetés}

\section{6. december 5. 11.00-12:45}

\section{Jelen vannak: Csongor Barnabás, Ferenczy Mária, Galambos Imre}

GI: Először is, Tanár Úr, a családi hátteréről ha tudna mondani valamit.

CsB: Hát igen, a családi háttér annyi, hogy én vagyok az első sinológus a családban, illetve bocsánat, hogy szerényebben fogalmazzunk, olyasvalaki, aki tevőlegesen érdeklődik Kína iránt, és nagyon könnyen lehet, hogy egyben az utolsó is, lévén hogy sem az elsőfokú, sem másodfokú, sem harmadfokú utódaim (tekintve, hogy dédunokám is van már) közül egyik sem mutatott hajlandóságot arra, hogy érdeklődjék Kína iránt.

FM: Mindez a családon belül értendő ugyebár.

CsB: És a rokonságban sincs.

GI: Honnan jön a család?

CsB: Hát, kérem szépen, apai részről Gömör megyeiek vagyunk, mégpedig bunyevácok, ami Gömörmegyében elég csodálatos dolog. A Csongor, mondanom sem kell, hogy magyarosított név. Az eredeti nevünk Krenics, ez valamilyen délszláv nyelven azt jelenti, hogy (most csúnyát mondok, mert latinul mondom), leuciscus leuciscus. Ez egy édesvízi halfajta, egy olyan $20 \mathrm{~cm}$ hosszúra szokott megnőni - ezt különben a lányom derítette ki.

GI: És a Tanár Úr hol született?

CsB: Miskolcon születtem, Miskolcon is éltem életem javarészét. Apám első generációs értelmiségi, apja is paraszt volt, és hát a felmenői - mint mondtam - bunyevác származásúak. Azt tudni kell, hogy a bunyevácok katolikus délszlávok, tehát majdnem horvátok. És hát a hagyomány szerint az akkori földesurak, a Serényi grófok telepítették őket valahonnan Bácskából vagy Baranyából (oda valósiak az eredeti bunyevácok) Gömör megyébe. De hát ez csak egy ilyen családi hagyomány, az tény, hogy a neve délszláv volt, így magyarázható meg a család neve. Ezt különben az inter- 
netről tudjuk, a lányom ezt onnét állapította meg. Anyai részről viszont német vagyok. Mármint a felmenőim, mégpedig apai részről, anyám apja valószínüleg porosz. Nyíregyházig tudjuk visszavinni, vagyis kétszáz évig. Anyai-anyai részről viszont svájci, mégpedig Graubünden kantonbeli. Szóval tisztességes kelet-európai család vagyunk.

GI: Milyen iskolába járt a Tanár Úr?

CsB: Katolikus elemibe, lévén hogy katolikusnak születtem. Tovább folytatódik ugye a kelet-európaiság, lévén hogy az apám katolikus, anyám viszont református, aminek következtében csak polgári esküvőt köthettek, mert anyám nem volt hajlandó, illetve szóba sem került, hogy reverzálist adjon.

FM: A fiúkat katolikusnak, a lányokat meg reformátusnak nevelték.

CsB: Pontosan. Aminek következtében engem időnként gyerekkoromban tört a frász, hogy szegény jó anyám el fog kárhozni, mert hittan órán, mondanom sem kell, hogy azzal tömtek minket, hogy szidták a reformátusokat. A zsidókat már nem is említették.

GI: És utána milyen iskolába járt a Tanár Úr?

CsB: Utána természetesen a Miskolci Királyi Katolikus Fráter György Gimnáziumba, tudniillik annak idején a Horthy Magyarországon Mária Terézia óta voltak nem szerzetes rendek által fenntartott, de mégis felekezeti iskolák. Miskolcon volt egy ilyen katolikus gimnázium, ez volt a Fráter György. Volt egy református gimnázium is. Tehát hozzánk csak katolikusokat vettek fel, illetve bizonyos számban izraelita gyerekeket. A református gimnáziumba ugyancsak.

GI: A Tanár Úr mikor és miért kezdett keletkutatással foglalkozni?

CsB: Abban az időben ez benne volt a levegőben, mert roppantul dúlt ugye a nemzeti érzés, a fajmagyarkodás, aminek én is, mint ifjú és lelkes fiatalember, buzgó híve voltam. Rengeteg nyomtatott és szóbeli megnyilatkozása volt akkor annak, amit később Zsirai tanár úr, aki a finnugor nyelvek professzora volt abban az időben a Budapesti Egyetemen, délibábos nyelvészetnek nevezett. Ezt biztos maga is ismeri. Attól az időtől kezdve, hogy Sajnovics János jezsuita csillagász a 18. században észlelte Norvégiában, hogy a lappok nyelve hasonlít a magyarokéhoz, azóta tudjuk azt, hogy a magyar nyelv a finnugor nyelvek közé tartozik. A magyar nemzeti büszkeség, nem utolsó sorban a nemesi önérzet ezt nem volt hajlandó lenyelni, hanem elkezdett bibliai és egyéb források alapján az égvilágon minden nemzettel és kultúrával rokonítani minket, illetőleg a magyarokat, kezdve a zsidókon, egészen a maja indiánokig. Erre vonatkozóan '44-ben ennek 
a bizonyos Zsirai Miklós professzornak jelent meg egy nagyon érdekes cikke „Östörténeti csodabogarak” címmel, ${ }^{1}$ és nemrégiben volt a kezemben egy ugyancsak magyar nyelvü kiadvány - A magyarok eredete vagy valami hasonló a címe - Keresztes Károlytól, amely nagyon komolyan és alaposan sorra veszi az összes ilyen délibábos elképzeléseket. ${ }^{2}$

GI: És mikor történt, hogy a Tanár Úr a Kelet felé orientálódott?

CsB: Hát már kezdődött a középiskolában. Apám jogász volt, ügyvéd volt Miskolcon. Parasztgyerekből lett ügyvéd és jogász. Elözőleg mint parasztgyereket, hát a szülei minek szánták volna? Papnak. Úgyhogy Rozsnyóban - ami akkor Magyarországhoz tartozott ugye, ezerkilencszázegynéhányban - a Premontrei Gimnáziumba járt iskolába azzal a szándékkal, hogy majd belép a premontrei rendbe. Ez egy tanító rend, a fehércsuhások. Érettségi után arról is volt szó, hogy belép a rendbe, de egy év után kilépett a rendből. Én kérdeztem tőle, hogy miért, ő kurtán csak annyit felelt, hogy „el akartak küldeni Rómába és én nem akartam menni”. A húgomnak többet mondott, neki még azt is mondta, hogy kiábrándult a papokból. Elég az hozzá, hogy akkor elöször elment volna matematika-fizikus tanárjelöltnek, de ez abba maradt és elment jogásznak. Így lett aztán belőle ügyvéd Miskolcon.

Úgyhogy 14-ben vagy mikor, az Első Világháborúban be is hívták katonának, kivitték az orosz frontra, be is került Szibériába hadifogságba vagy 4-6 évre. Ezekről nem tudok biztos dátumokat, mert ezekről sosem beszélt. Úgyhogy erről nem tudok közelebbit, csak gyanítom, hogy olyasmi eszméket szedhetett ott fel, hogy amikor később hazakerült '19-20-ban, azokat idehaza nemigen lett volna tanácsos emlegetni. Nem mintha - mit tudom én - kommunista lett volna vagy hasonló, mert ennek nyomát sem láttam később. Szóval mindenesetre meglehetősen hányatott sorsa volt. Elég az hozzá, hogy a hadifogság után 1919-1920-ban Szibérián keresztül - mint csehszlovák állampolgár, lévén hogy mint ilyesmit kezelték a szibériai fogolytáborok feloszlatása után - Vlagyivosztokba került. Akkor az újonnan alakult csehszlovák kormány, nyilván az Antant támogatásával, a jövendő állampolgárai számára bérelt egy hajót és azzal hozta őket haza. Mint ilyen csehszlovák állampolgár, atyám is erre a hajóra került. Erről

1 Zsirai Miklós 1943. „Östörténeti csodabogarak”. In: A magyarság östörténete. Szerk. Ligeti Lajos. Budapest.

2 Itt valószínüleg Nagy Károly Öshazakeresőink Nyomában című könyvéről van szó, amely 2003-ban jelent meg. 
sem beszélt részletesen, fogalmam sem volt arról annak idején gyerekkoromban, hogy ennek mi volt a háttere. És hát ennek következtében, mintegy jóvátételként a szibériai hadifogságra, Vlagyivosztokból beutazta a fél világot. A Gibraltáron keresztül, megkerülve Afrikát, vagy a Szuezicsatornán keresztül, azt már nem is tudom, a lényeg az, hogy Egyiptomban például kiszállt és megnézte a piramisokat meg hasonlókat. Tehát kapott egy kis világkörüli utazást.

A legnagyobb meglepetésére, amikor Triesztben felültették a vonatra, meg sem álltak talán Kassáig vagy meddig, ott pedig fogadták őket és eljátszották tiszteletükre a csehszlovák himnuszt. Úgyhogy aztán, amikor valamennyire tájékozódni tudott, mert hiszen nyilván nem volt egyedül magyar nemzetiségü csehszlovák hadifogoly, egyik éjszaka szépen átlépett a határon és hazament Putnokra. Ez volt az ő szülővárosa. Putnokról aztán bejött Miskolcra, Miskolcon bevégezte még az egyetemi jogi vizsgáit. Ezeket különben folytatta a hadifogságban is, mert azt azért lehetett csinálni, sőt azt hiszem maga is okított már másokat a jogra. Ö maga iskolából tanult németül, a hadifogságban megtanult valamelyest oroszul, azonkívül angolul és franciául. Tehát a nyelvtudás úgy látszik ment a családban. Eljött Miskolcra, ott megismerte anyámat a miskolci Aranyszarvas patikában, amelyik akkor anyámék anyai ágú családjának egyik részéhez tartozott. Összeházasodtak, és hát így születtem meg 1923-ban.

GI: De ha mint csehszlovák állampolgárt tartották számon, akkor gondolom szlovákul is tudott, nem?

CsB: Nem. Legalábbis erről soha nem volt szó. Miskolc környékén vannak szlovák falvak, talán még máma is, azokon én megtanultam valamelyest, egy pár szót szlovákul. Apám esetében ezt sosem hallottam.

GI: Térjünk akkor vissza arra, hogy a Tanár Úr hogyan kezdett el a Kelettel foglalkozni?

CsB: A Kelettel foglalkozás meg ezzel a bizonyos délibábos nyelvészettel indult. Akkor például nagyon nagy divat volt a sajtóban és közkiadásban is a magyar-japán kapcsolat és rokonszenv. Sőt, a magyar-japán rokonság. Úgyhogy a Kelet iránti érdeklődésem abban csúcsosodott ki úgy hetediknyolcadik gimnáziumban, hogy a magyar-japán rokonsággal fogok foglalkozni és be fogom bizonyítani, hogy nem is igaz, hogy mi finnugor nyelv vagyunk, hanem a japánokkal vagyunk rokonságban. 
GI: És hogyan lett ebből karrier, pálya?

CsB: Tulajdonképpen roppant egyszerủen lett ebből sinológia. Közben történt az, hogy 1938-ben - hát ez is Kelet-Európa - jött az Első Bécsi Döntés, ahol az akkori Magyarország szövetségesei, tehát a Náci Németország és a Fasiszta Olaszország jóvoltából a Trianoni Békével elcsatolt országrészek egy részét, amelyek túlnyomórészt magyar lakossággal rendelkeztek, viszszaadták Magyarországnak. Az Első Bécsi Döntés alkalmával, ami 1938ban történt, Szlovákia déli, máig túlnyomórészt magyar-lakta részét visszacsatolták Magyarországhoz. Ehhez persze létre kellett hozni egy megfelelő magyar hivatali apparátust is, például bírókat kellett kinevezni, és ehhez toboroztak nagy jogi tapasztalattal rendelkező egyéb jogászokat, például tapasztalt és idős ügyvédeket. Úgyhogy apám, nem utolsósorban anyám biztatására, mert azért ügyvédnek lenni elég bizonytalan valami volt, nem járt fix fizetéssel, apám megpályázta ezt a hivatali állást, aminek a feltétele az volt, hogy minimum két évet vállalni kellett az új területen. Úgyhogy így kerültünk mi akkor 1939-ben Beregszászra. Apám mint vizsgálóbíró, mi pedig hát mint család. Aminek megvolt az az előnye, hogy törvény szerint ugye a bírói függetlenség garantálása végett bírót csak saját kérésére lehetett áthelyezni, viszont azt vállalni kellett a kinevezés miatt, hogy a minimum két évet ezen a helyen töltünk el.

GI: Na és a Kelet?

CsB: Lássa, milyen bonyolult ez a kis Kelet-Európai történet. Mert az, hát világtörténelmi szempontból egy kabaré vagy nem is tudom micsoda.

GI: Hát mindenhol bonyolult a történelem.

CsB: Szóval olvastam ezeket a fantasztikus könyveket, hát volt még olyan is, ami hát még például nyugaton azt hiszem máig nagy divatban van, mert amikor '57-ben kikerültem Amerikába, a könyvesboltokban láttam a piacon egy müvet, hogy az emberiség bölcsője a Mu földön volt (biztos maga is látott valami ilyesmit), ami nem is az Atlantisz volt az Atlanti Óceánban, hanem a Csendes Óceánban süllyedt el, mégpedig a szerző szerint (egy George Wall nevü angol szerint) időszámításunk előtt tizenkétezer évvel. ${ }^{3}$ De mindegy. Szóval akkor egy erről szóló könyv megjelent magyarul, én sürgősen megszereztem, föllelkesedtem és előadást tartottam róla.

3 Itt valószínüleg James Churchward (1851-1936) angol íróról van szó, aki eredetileg 1925-ben publikálta The Lost Continent of Mu címü könyvét, amelynek számos későbbi kiadása is megjelent. 
Beregszászon persze a visszacsatolt terület népe az anyaországból jött tudós fiatalembert áhítattal hallgatta. Hogy magukban mit gondoltak, az más kérdés. Szóval zavaros ember voltam nagyon.

Úgyhogy mikor leérettségiztem, atyámnak természetes lett volna, hogy folytatom az ő szakmáját. Nagyon szép gazdag jogászi könyvtára volt, de hát én arról hallani sem akartam. Különben sem voltam jóban apámmal, mint az nagyon sok fiúgyerekkel megtörténik. Hanem mondtam, hogy én pedig keleti nyelvész akarok lenni. Mégpedig japán. Hát erről viszont anyám sem akart tudni, révén hogy ,édes fiam, hát éhen fogsz halni, mint a Körösi Csoma Sándor.” Hát anyám nem tudta, hogy Csoma Sándor éhen halt-e vagy nem, a lényeg az, hogy meghalt. Tehát nem tudtunk megegyezni, úgyhogy kiegyeztünk középúton, hogy akkor legyek közgazdász. Mert akkor nem is jogász, de nem is keleti nyelvész, és ott müködik a Keleti Nyelvek Intézete. Azt valamikor a kilencszázas években, a Monarchia idejében alapították, a Monarchia keleti irányú terjeszkedési irányában. Ebben az intézetben annak idején törököt, arabot, perzsát, szerbhorvátot meg ilyeneket tanítottak. Én el is mentem a Közgazdasági Egyetemre, ami akkor a Müegyetemhez tartozott a változatosság kedvéért. Megkerestem a Keleti Intézetet. Az állt a Germanus Gyulából, aki törököt, arabot és perzsát tanított. Ebből állt az egész intézet, japánról szó sem volt.

Két féléven keresztül bírtam, az első félév Karácsonyán leborultam apám-anyám előtt és mondtam, hogy ez nekem nem megy, ez nekem nem köll, legyetek szívesek engedjetek el engem japán nyelvésznek. Na, erre nem mondtak semmit, de hát mondták, hogy azért fejezzem be a közgazdaságit, legalább a második félévet, hogy valamink legyen. El is mentem, és közben apám - örök életemben csak hálás tudok lenni neki érte, akármennyire nem értettük meg egymást addig - ekkor megértett engem, tudniillik tudtom és beleegyezésem nélkül, de teljesen utólagos jóváhagyásommal beadta a kérvényemet az Eötvös Collegiumba. Ez egy Eötvös Loránd minisztersége idején 1895-ben alapított elit tanárképző intézet volt, amelyik a magyarországi középiskolai tanárság színvonalát volt hivatva emelni, és amelyik aztán létezett ebben a formában egészen 1947-48-ig. Formailag középiskolai tanárokat képezett, mégpedig az akkori szokás szerint kétszakosokat. De emellett a tanárai, akik aztán nagyrészt később magának ennek a kollégiumnak a végzett hallgatói, neveltjei voltak, külön felvételi vizsgát rendeztek ebben a kollégiumban, amelyre rendszerint a kollégiumban végzett középiskolai tanárok küldték kiválónak látott, arra 
alkalmasnak látszó diákjaikat. Valahogy talán miskolci tanári ismerőseitől tudta meg ezt apám, vagy tudta hamarább is, azt már nem tudom, mert hiszen nem voltam vele olyan bizalmas viszonyban, hogy erről beszélgettünk volna.

Az Eötvös Collegium alapjában véve középiskolai tanárokat képezett, mégpedig színvonalasabbakat, mint általában a többi középiskolai tanárjelölt. De emellett egy sajátos értelmiségi elitképzés is folyt. A kollégium tanárai rendszerint a középiskolák ajánlásai alapján vették fel az új egyetemi hallgatókat a kollégiumba. Így az Eötvös Collegium utánpótlása a középiskolák érettségiző diákjai közül került ki, rendszerint ha az illetőnek voltak a kollégiumban végzett tanárai. Ez azonban nem korlátozódott a tanári pályára. Bár a kollégiumba csak tanárjelölteket vettek fel, tehát magyar-német, angol-francia, történelem-földrajz, stb. két tanári szakkal rendelkező tanárjelölteket. De ugyanakkor külön gondot fordítottak kezdettől fogva azokra a tehetségesnek látszó fiatalokra, akik különböző és egyetemi keretek közé nem szorítható, vagy meg nem valósítható, nem képviselt szakmák iránt érdeklődtek. Ez néha bevált, néha nem vált be.

Többek közt kollégista volt Kodály Zoltán, aki pedig zenész. Vagy nem tudom én, Szabó Dezső, az író, aki viszont, tekintve, hogy mindenkivel összeveszett, hát a kollégiummal is összeveszett és egyetlen jó szava az emlékirataiban a kollégiumról nincsen. A kollégiumon belül négyes „,családokba" voltunk osztva, és ilyen kétszobás, négyágyas, négy íróasztalos lakrészekben laktunk a kollégiumon belül. Ide tartozott Szőllősy András zeneszerző, aki egy csodálatos ember volt, aki amikor bekerültem a kollégiumba, mindig aludt és ott állt az asztalon egy cédula, hogy „Gólyácska, költsél engem föl fél kilenckor!” Ugye hát én voltam a gólya, a legfiatalabb, nekem kellett ezeket a kötelezettségeket teljesíteni. Aztán amikor fél kilenckor elkezdtem költeni, hát mondanom sem kell, hogy nem akart fölkelni, mert olyan későn feküdt le. Az éjszakát rendszerint valamelyik, hogy mondjam, ligeti padon töltötte, rendszerint nem is egyedül. És aztán mindenből jelesre vizsgázott, és amikor letette az utolsó vizsgáját, addigra megírta az első könyvét [cikkét] Kodály kórusainak zenei szimbolikája címmel. ${ }^{4}$

De hát ilyenek voltak a többiek is. Egy csomó huszadik századi író is került ki onnan. '31-ben le is lepleztek a kollégiumban egy kommunista

4 Szőllősy András 1943. „Kodály kórusainak zenei szimbolikája”, Magyar Zenei Szemle iii: $35-44$. 
összeesküvést. Ide tartozott Bartók Bélának az öccse, Bartók János, akivel aztán találkoztam később. Már meghalt az is, Atya Isten! Hát persze hogy meghalt, jóval idősebb volt nálam. Szóval elég az hozzá, hogy a vidéki intellektuális nyomorúságból egy olyan intellektuális légkörbe kerültem, ahol nagyon erősen meg kellett kapaszkodni ahhoz, hogy az ember megtalálja és megőrizze a helyét. Nem szólva arról, hogy amikor felvettek a kollégiumba, akkor is jellemző volt, hogy velem együtt legalább még négy gyerek akart keleti nyelvész lenni az első évben. Az egyik, a legkomolyabbat említve, egy óbudai tüzoltó tíz gyereke közül a legidősebb, aki akkor már, tekintve hogy óbudai lakos volt, bejáratos volt a Török Tanszékre, mert ő turkológus akart lenni. Egy csomó mindent tudott, pertu barátságban volt a professzorokkal és szakirodalom után nyúzta őket, és olvasta. Ragyogó egy koponya volt és aztán a végén nem lett belőle turkológus, mondanom sem kell. Túl jó volt valahogy ehhez. De elég az hozzá, hogy szerencsémre a szárnyam alá nyúlt, és jóbarátok lettünk, és sok mindent elmagyarázott nekem, szegény vidéki árvának.

Volt egy másik, a Kassai Jóska, aki középiskolás létére ritka kivételképpen tudott oroszul, úgyhogy úgy nézett ki, kaukázista nyelvész lesz. Volt a Györffy Sándor, a nagy Györffy néprajzosnak az oldalági rokona, az japanista akart lenni. Talán több nem is volt. Szóval mi voltunk négyen. Mit tesz Isten, én maradtam meg közülük egyedül a szakmában. Nem személyi kiválóságaim következtében, hanem azt hiszem, egyszerüen egy ilyen sajátos nehézkedés következtében. Márcsak azért is, mert a kollégiumba a jelentkezés úgy ment, hogy arra az időre az ember három napra beköltözhetett a kollégiumba. Ez a nyári szünidő eleje volt, amikor a kollégisták már hazamentek, és az újak még nem kerültek be. A felvételizők beköltözhettek, fogadta őket az igazgató, és az igazgató előtt megmondták, hogy milyen szakra jelentkezzek. Hát én kivágtam, hogy japánt akarok tanulni!

Az igazgató az jámboran közölte velem, hogy hát azt nem lehet, hanem tessék megmondani, hogy milyen tanári szakra tetszik jelentkezni. Gondolkodtam azon, ha már tanári szakról van szó, miben voltam a legerösebb? Hát gondoltam, magyar-latin. Rendben van, a kezembe nyomott egy cédulát, amin rajta volt tíz név, tíz tanárnak a neve, akik erre az időre szintén három napra beköltöztek a kollégiumba. Mert a kollégium be volt rendezve szeminárium-képzésre is, tehát lakószobák voltak benne és voltak tantermek. És ezek a tanárok is különböző tantermekben foglaltak helyet, 
és a cédulával a kezemben sorra jártam őket (ki voltak írva a nevük az ajtóra), közvetlenül amikor éppen ki tudtam fogni valamelyiket, hogy ráér, $\mathrm{s}$ amikor számomra is kijött a lépés. Közvetlen beszélgetést folytattak velem, kifaggattak általános müveltségemröl, tájékozottságomról, nyelvtudásomról legkülönbözőbb nyelvekből. A végén ezek a tanárok összeültek és közösen eldöntötték, hogy kit érdemes felvenni a kollégiumba, kit nem.

Én ekkor ismerkedtem meg leendő tanárommal, Ligeti Lajos profeszszorral. ${ }^{5}$ Azt tudni kell, hogy 1924 óta volt a Pázmány Péter Tudományegyetem Bölcsészkarán Kelet-ázsiai Tanszék, amelyet Ligeti professzor elbeszélése szerint politikai okokból alapítottak. Ugyanis 1924-ben vagy előtte valamivel képviselőválasztáskor ellenzéki jelöltként, tehát a kormánypárttal szemben, ellenzéki programmal fellépett egy bizonyos Pröhle Vilmos. ${ }^{6}$ Nem tudom, ismeri-e a nevét?

GI: Persze, igen. A Keleti Szemlében publikált.

CsB: Emellett a Pröhle Vilmos germán neve ellenére harcos fajmagyar volt és harcos antiszemita. Tehát még a Horthy-korszakhoz képest is jobbra állt. Többek közt tervei közt szerepelt, hogy a Gellért-hegyre építtet egy Magyar Pantheont, élén a magyarok istene szobrával, amiből aztán szerencsére nem lett semmi. A dolog humora az volt, hogy a Pröhle német származása ellenére fajmagyar volt, a leánya viszont tüzes népi német volt és volkbundista. Ez a Németországon kívüli német kissebbségek náci párti egyesülése volt. A lánya nagy bánatára Pröhle nem volt hajlandó belépni a Volkbundba, mondván hogy ő magyar és nem német. A lánya ennek ellenére németnek vallotta magát.

FM: Most az az érdekesebb, hogy Pröhlének csinálták a tanszéket, hogy ne lépjen fel mint ellenzék, ugye?

CsB: Igen, hogy ne lépjen fel ellenzéki politikusként. Abban az időben viszont egy ilyen tanszéknek a vezetője - amelyik tanszék például nem képzett tanárokat, hanem szabadbölcsészeket - azt jelentette, hogy az illető meghirdethetett olyan előadásokat, amelyek neki tetszettek. Tehát a legszorosabb

5 Ligeti Lajos (1902-1987), orientalista nyelvész, egyetemi tanár, a mongol és török nyelvek világhírü szakértője. Amint az interjúból is kitünik, jelentős szerepe volt a magyar keletkutatás megteremtésében.

6 Pröhle Vilmos (1871-1946), egyetemi tanár, a Pázmány Péter Tudományegyetemen Kelet-ázsiai Intézet első professzora. Elsősorban mint turkológus tevékenykedett, de páratlanul széles nyelvismeretének köszönhetően tucatnyi más nyelvet is tanított pályafutása során. 
értelemben vett szabadbölcsészet volt ez. Amennyiben nyolc féléven keresztül hallgatta öt egy hallgató, és a leckekönyvéböl kiderült, hogy le is vizsgázott belőlük, akkor a nyolcadik félév végén kapott egy végbizonyítványt, ami bizonyította, hogy elvégezte az egyetemet, de ami az égvilágon semmire sem képesítette őt. Illetve, ha tanári diplomát akart szerezni, akkor emellett még el kellett végeznie a Tanárképző Intézetet is, ami tulajdonképpen azonos volt a Bölcsészkar bizonyos tantárgyaival, tehát plusz fáradtságot nem jelentett. De emellett még hallgatnia kellett még filozófiát, etikát és pedagógiát. Erre kaphatott tanári diplomát.

Ligeti ott ült ebben a vizsgáztató társaságban, akkor láttam életemben először. Turkológus barátom, az már, hogy mondjam, régi barátságban volt vele. Nemcsak vele, a többi keleti nyelvészprofesszorral is, Német Gyulával, aki a turkológia professzora volt. Szóval, amikor bekopogtam Ligetihez, mondanom sem kell, hogy azzal kezdődött, hogy úgy képzeltem, hogy amikor megkérdezi, hogy mit akarok és közlöm vele, hogy japánnal szeretnék foglalkozni, akkor azt fogja mondani, hogy „Kedves barátom, örülök a szerencsének, foglaljon helyet!", és fogad mint jövendő hallgatóját. Ezzel szemben nem ez történt velem.

Ligeti azt mondta, hogy „Mi!?” És aztán hozzátette: „Hogy mondta!?” Megismételtem. Erre előrébb dugta a képét a székben, ilyen nagy balta formájú szőke feje volt. Azt hittem, hogy ősz, pedig csak szőke volt. „Mit mondott? Hát idefigyeljen, tud maga németül?” Mondom: „Tudok”. Hátranyúlt a polcra, levett egy könyvet: „Olvasson, fordítson!” Olvastam, fordítottam. Azt mondja, „Köszönöm, elég! Na, angolul?” Lenyúlt, vette a következő könyvet: „Olvasson, fordítson! ”Hamar abbahagytam. „Franciául?” Az már még lassabban ment. „Oroszul?” „Nem tudok.”,Japánul?”,Nem tudok.”,Kínaiul?” „Nem tudok”. „Hát idefigyeljen! Ezt mind meg kell tanulni! És? Nem, ez még mind nem tudomány. Ekkor jön a tudomány. Ekkor kezdődik. És? Nem, éhen fog halni. Állás nincs! Ezek után mit akar?” Kutyaszorítóban voltam, „Hát japánt”. „Japán sincs!” Még nem volt japán, tudniillik ő japánul nem tudott, nem is érdekelte, nem foglalkozott vele. És a japán lektor ekkor ment haza. Mint kiderült, el is jutott a szerencsétlen a Kaukázusig és ott valahol valami baj érte, mert sose ért aztán haza. Úgyhogy amikor'57-ben találkoztam először Japánban japánokkal és meghallották, hogy még beszéltem vele, nagy érzékenyen fogadtak azzal, hogy én voltam az utolsó, akit ismertek, hogy még életben találta az illető tanárt, bizonyos Sugehirot. Na de ez mellékes. „Na most idefigyeljen, 
vagy tanul kínaiul, vagy elmegy a fenébe!” Hát mit lehetett csinálni? „Tanulok kínaiul.” Így lettem kínai szakos.

Ez persze úgy történt, hogy eddig, 1942 öszéig Pröhle Vilmos volt a Keletázsiai Tanszék vezetője, de Pröhle Vilmos úgy mellesleg tudott kínaiul is, de a fő szerelme neki a japán volt, lévén hogy ő is, mint fajmagyar, a japán-magyar rokonság lelkes híve volt. A turánizmus jeles híve volt, de amellett tudományos publikációja neki nemigen volt, sinológiából aztán végképp nem volt. De állítólag különben emellett a kínai meg a japán mellett tudott valami negyven nyelvet, de hát ilyeneket, hogy héber (tehát héberül olvasta a Bibliát), vagy tudott vogulul, ami ugye az első olyan nyelv, ami a legközelebb áll a magyarhoz. És hát állítólag megcsinálta azt a viccet, amikor Nyíregyházán tanárkodott, hogy baráti körben ebéd elött elimádkozta a Miatyánkot negyven nyelven. De hát ez csak mese, mert én egyszer találkoztam vele társaságban, már a Magyar Keleti Társaságban, de ott is csak láttam. Kis, alacsony, bozontos ősz hajú ember volt, fekete mundérban, ami igen emlékeztetett az SS-eknek, pontosabban a náci irányultságú német értelmiségieknek az egyenzubbonyára. Tehát amellett, hogy fajmagyarnak tartotta magát és nem lépett be a Volkbundba, maradéktalanul hívének mutatkozott a nácizmusnak. Szóval Pröhle ezzel le is került a napirendröl. Elkezdtem Ligetit hallgatni.

Tekintve hogy a magyar orientalisztikának egyik fontos ága volt abban az időben - amelyet politikailag a kormány is félhivatalosan fontosnak tartott - hogy a magyar történelem kezdeteinek tudományos vizsgálatát részletesebben kimunkálják, mert az ország politikai hitelét is erősen csorbította ez a délibábos nyelvészet. Ligeti idehaza latin-magyar szakos diplomát szerzett a kollégiumban, majd ösztöndíjat kapott, hogy Párizsban tanuljon, és Párizsban nagynevű francia sinológusoktól tanult mongolisztikát. Magyarországon tanult turkológiát, tanult persze finnugor nyelvészetet is, magyar nyelvészetet is, megtanult még mellesleg perzsául és arabul. Arabul talán nem, de perzsául és törökül biztosan. És azért is perzsául, mert később aztán elment Afganisztánba a '30-as években az afganisztáni mongol kisebbség nyelvét tanulmányozni, és ehhez kellett tudnia perzsául. És az Afgánföldön címü könyvéből is kiderül, hogy tudott perzsául.

Pröhle egy ilyen nagyúri módon kezelte a professzorságot, mint az akkori nem tanárképző professzorok nagy része is, hogy tudniillik azt adott elö, amit kedve szerint előadott, és volt professzor, aki időnként kiírta, hogy ezen a héten óráimat nem tartom meg, és senki nem szólt egy 
szót sem. De ha túl sokszor csinálta, akkor persze a kari tanács meg a felsőbb hatóság már szóvátette, hogy professzor úr, kérem, mégiscsak azért a fizetésért kellene valamit csinálni. De úgy általában a tanszabadság az teljesen biztosítva volt.

Ligeti viszont ezzel ellentétben nagyon komolyan vette, hogy ő továbbviszi a magyar orientalisztika ügyét. Tehát amit lehetett, nemcsak hogy felszedte Párizsban, hanem azt igyekezett Budapesten tovább is kamatoztatni. Tehát amikor Pröhle elment nyugdíjba, arról volt szó, hogy a KeletÁzsiai Intézetet bezárják és a könyvtárát raktárba helyezik, és egészen addig, amíg valahonnét nem kerül elö egy fiatal - vagy nem fiatal - magyar tudós, akire rá lehet bízni egy Kelet-Ázsiai Tanszéket, addig a Kelet-Ázsiai Tanszék egyszerüen alszik, nem létezik. Hogy a kínai oktatás fennmaradjon, vagy hogy egyáltalán létrejöhessen, Ligeti vállalta, hogy a saját tanszéke mellett, amit ekkor kreáltak neki és amit Belső-Ázsiai Intézetnek neveztek el, és amelyikbe turkológia és tibetisztika tartozott, vezeti a KeletÁzsiai Tanszéket is. Ez annyit jelentett, hogy heti két órában mongolt, heti két tibetit, és heti két órában kínait tanított.

Persze a tanítás abból állt, hogy leadta az anyagot nekem és néhány pár embernek, akik aztán hamarább lekoptak. De ő, mint szabályos nyelvtanár, nagyon komolyan vette az okítást. Mindenkinek minden órára készülni kellett. Létrejött akkor Leon Wieger tizenkilencedik századi jezsuita atyának (aki egyike volt a tizenkilencedik századi francia sinológia termékeny mủvelöinek) egy kis füzetecskéje, amiben a kínai nyelvtan vázlatát írta meg. Tulajdonképpen ezt a változatot adta le Ligeti, mert felmérte, hogy heti két órában ezt tudja előadni azok számára, akiknek egyáltalán sinológiát érdemes tanítani. Heti két órában mongolt, heti két órában tibetit.

Volt neki már persze haladottabb hallgatója is, nálam idősebb, aki már mindezeket hallgatta őnála is. Kínait is hallgatott. Egy bizonyos Nagy Lajos Gyula és egy másik fiatalember, az Uray Géza, aki viszony tibetit tanult. Nagy Lajos Gyulát, aki aztán '46-ban meg is szerezte a doktorátust, de az a végzet érte utol, hogy '45-ben hazament a falujába és segített a bátyjának erdőben fát vágni, mármint kivágni egy nagy fát, mert a bátyja éppen építkezett és fát kellett dönteni hozzá. Szegény Gyula megfázott, kapott egy csont TB-t és évekig feküdt kórházban. Akkor, mikor kiszabadult, felkereste öt egy nyugatról akkor hazajött hajdani osztálytársa. Erról az osztálytársról csakhamar kiderült, hogy be akarta szervezni az angol 
kémszolgálatba. Megtalálták az iratait, benne volt a Lajos [Gyula] lakcíme, letartóztatták, internálták, ezzel vége volt. A csont TB végzett vele. Ő volt az egyik.

Az Uray Gézát elvitte a hadifogság, orosz fogságba került. Aztán hazajött, csak jóval később, valamikor '46-ban vagy '47-ben. A lényeg az, hogy a történelem szépen kirostálta mellőlem a többieket. A barátom, a ragyogó fejü turkológus, aki hát ugyanakkor a demokrácia számára egy tőről metszett jövendő értelmiségi volt, tüzoltó volt az apja, tehát igazi proli gyerek volt, és egy ragyogó koponya, nagyon jó fej, rájött arra, hogy neki mégsem kell a turkológia. Rájött arra, hogy ő költő. Elkezdett verseket írni. Közben elment, jelentkezett a demokratikus rendőrségbe, már nem tudom, milyen okból. Ott volt, amikor Mindszentyt letartóztatták, mesélt jó dolgokat, satöbbi. Szóval ô is otthagyta a szakmát.

A lényeg az, hogy lényegében egyedül maradtam a szakmában és mint Ligeti professzor hallgatója. Ligeti nagyon keményen fogta a dolgát, mert nemcsak hogy leadta ezt a bizonyos kivonatát a kínai grammatikának, hanem a markomba nyomott egy kötet Legge-t, ${ }^{7}$ ugye a Lunyu-t, abban a kínai szöveg, kommentárok és angol nyelvü fordítás, és havonta kikérdezte, hogy mit végeztem belöle. És nem viccelt, minden trükköt ismert már mint öreg tanár, úgyhogy sosem az elejétől kérdezte, hogy mit olvastam, hanem a végéröl. Hogy ha azt mondtam, hogy hat oldalt olvastam, akkor a hatodikat kérdezte, nem az elsőt. Úgyhogy csakhamar rá kellett jönnöm arra, hogy itt bizony, ha meg akarok maradni, akkor dolgoznom kell.

Ez rendben ment szépen 1944-ig, majd '44 nyarán jött a német megszállás. Akkor én már nem is jöttem fel Pestre, hanem otthon maradtam Miskolcon. Nota bene, akkor történt, hogy így a dolog még szebben sikerüljön, bombát kapott a tanszék, úgyhogy a tanszék könyvtára kiégett. Az egész Kelet-Ázsiai Tanszékből és a jövendő Belső-Ázsiából annyi maradt meg, ahány könyv Ligeti professzornál meg a hallgatóinál otthon volt kölcsönbe és amelyeket ismételt figyelmeztetés és sürgetés ellenére nem

James Legge (1815-1897), skót misszionárius, akit elsősorban a kínai klasszikusok fordítójaként ismert. Ezek többnyire kétnyelvü kiadványként jelentek meg és tartalmazták mind az eredeti kínai szöveget, mind az angol fordítást, illetve az ahhoz írt kommentárt. 
vittünk vissza. Ebbe tartozott Bernhard Karlgrennek ${ }^{8}$ az Études sur la phonologie chinoise címü klasszikus munkája, ami pocsék franciasággal íródott, ennek ellenére a kínai nyelvtörténetben korszakot jelentett a megjelenése. Ez adta a Ligetinek az ötletet, hogy nekem indítást adjon és ezért nem is tudtam eléggé hálásnak lenni.

Tehát az első nagy dolog az volt, hogy apám feltárta előttem a lehetöséget, hogy a kollégiumba kerüljek, a kollégiumban találkoztam Ligetivel, Ligeti pedig számot vetett azzal, hogy a nemzetközi sinológia más központjaiban nevelkedettekkel reménytelen lett volna felvennem a versenyt, mert hiszen francia, angol, német sinológia tanszékeken száz éve, kétszáz éve, Franciaországban talán háromszáz éve gyüjtötték már a sinológiai anyagot és a kínai könyveket, nálunk pedig, mit tudom én, öt vagy hat könyv volt. Nem is szólva arról, hogy a nagy könyvtárak, mint az Akadémia Könyvtára, gyüjtökörébe a sinológia tulajdonképpen nem tartozott bele. Az ilyen sorozatokat, mint a Sacred Books of the East, amibe James Legge-nek a klasszikus kínai konfuciánus és taoista müvek bilingvis kiadásai tartoztak, megvoltak ugyan, de már eredeti kínai kiadású könyvek nem.

Tehát ismét a Ligetinek az éles elméjét dicséri, hogy megtalálta nekem azt a területet, amin ilyen sanyarú viszonyok mellett is sikerrel vehettem fel a versenyt (ha megfelelő munkát végzek) a nemzetközi sinológiával. Ezt pedig a megmaradt könyvállomány lehetővé tette, tudniillik a témám, amit kiadott nekem, a Tang- és Song-kori, nem kínai, elsősorban régi ujgur szövegek kínai szórványainak a nyelvtörténeti vizsgálata. Tudniillik, a hetedik-nyolcadik századtól már meglehetősen gazdag volt az irodalom, amit belső-ázsiai népek Kínán keresztül a buddhizmustól kaptak, a saját nyelvükre lefordítottak, akár tibetire is, akár régi ujgurra, akár más egyéb belső-ázsiai nyelvre. És amellett hogy lefordítottak, bizonyos terminusokat, amiket nem egyszerüen lehetett lefordítani vagy nem volt mód lefordítani (például munkáknak a címét), azokat egyszerúen átírták a saját nyelvükre, a saját ábécéjükre.

Tehát a témám, amin dolgoztam, az úgy hangzott, hogy kínai szövegek és szórványok ujgur írással a Tang-korban. Itt egyszerüen azt kellett csinál-

8 Bernhard Karlgren (1889-1978), svéd nyelvész, aki a kínai nyelv fonológiai kutatásának legfontosabb úttöröje volt. Az 1915-ben megjelent Études sur la phonologie chinoise Karlgren doktori disszertációja volt, amelyet számos nagy jelentőségű publikáció követett. 
nom, hogy elővenni ezeknek a szórványoknak az ujgur írással leírt alakját és mellétenni a kínai eredetit. Ezt legtöbb esetben nagyon könnyen meg lehetett állapítani, mert hiszen a szövegek a buddhista kánon ismert darabjai voltak, rájuk lehetett ismerni magából a barbár nyelvü szövegből, tehát még a buddhizmusban való jártasságot sem kívánták meg. Az Études sur la phonologie chinoise alapján odaírtam melléjük a Karlgren által rekonstruált, a Karlgren által Ancient Chinese-nak nevezett hangértékeket, és ezek alapján elkezdtem ókumlálni, hogy vajon hogy is nézhetett ki ez a tibeti, pontosabban ekkor még csak ujgur írással átírt hangalak, hogy hangozhatott ez az eredeti kínaiban. Amikor ezeket azonosítottam, leírtam, listába szedtem és megpróbáltam ebből bizonyos következtetéseket levonni.

Ez tulajdonképpen nem volt más, mint egy ilyen, hogy mondjam, kritikai vizsgálata ennek az egésznek, ahol esetleg téves olvasatok voltak. Ilyen nagyon kevés volt, mert az illetők, aki ezeket a szövegeket kiadták, azért maguk is tudtak kínaiul, nemcsak egyszerüen tibetiül vagy ujgurul. Mert hiszen ehhez az anyaghoz kínai tudás nélkül nem is igen lehetett volna hozzányúlni, csak az nem jutott eszükbe, hogy nyelvtörténeti szempontból feldolgozzák őket. Úgyhogy ezt a feldolgozást végeztem el Ligeti javaslatára és megbízásából. Később áttértem a tibeti átírásos kínai szövegek vizsgálatára. Ebből írtam meg aztán a doktori disszertációmat: Tibeti irásos kínai szövegek és szórványok a Tang-korban. Mert mint kiderült, ezt sikerült nyelvtörténetileg igazolni, ezek a Tang-korig mennek vissza.

IG: Ebben az időszakban, amikor a Tanár Úr már a disszertációján dolgozott, nemzetközi viszonylatban kikkel álltak kapcsolatban?

CsB: Na most ne felejtse el, hogy 1949-ben történt egy nagy változás. Két irányban is. Az egyik irány az volt, hogy megalakult a Kínai Népköztársaság, aminek következtében Magyarország is, Kínai is szocialista ország lett. Tehát a Kínával való kapcsolatok és a kínai lehetőségek mértéken felül is, történelmileg először Magyarország és Kína közt rendkívüli módon kiszélesedtek. A másik oldalon meg az volt, hogy ugyanakkor Nyugat felé ekkor ereszkedett le a vasfüggöny, a fordulat éve, ahogy idehaza nevezték,vagyis gyakorlatilag lehetetlenné vált a kapcsolatok felvétele a világ nyugati felével. A szovjet sinológiával meg egyszerüen nem volt érdemes felvenni a kapcsolatot, mert a keserü humora ennek a szocialista világrendszernek az volt, hogy nemcsak Nyugat felé volt gyakorlatilag lehetetlen kapcsolatokat Magyarországon felvenni, de a Szovjetunióval is. Ott is 
nagyon nehezen. Tudniillik a szovjet vezetés,úgy látszik, hogy mondjam, mértéken felül félt a nyugati diverziótól, hatástól, befolyástól, fene tudja, mitől. Tehát nem is igen lehetett.

Ami viszont a Kínával való kapcsolatokat illeti, az elsőrendü igény a szocialista Magyarország és a szocialista Kína között a diplomáciai kapcsolatok felvétele volt, tehát a megfelelő káderek képzése ezen a két vonalon. Én nem akartam diplomata lenni, de senki meg sem kérdezte, hogy akarok-e diplomata lenni és, mit tudom én, a pekingi Magyar Követségen dolgozni vagy ilyesmi. Hanem egyszerüen amellett, hogy létezett Budapesten a Kelet-Ázsiai Tanszék Ligeti vezetésével és velem, mint tanársegéddel, amellett létrejött egy magyar - kínai kulturális egyezmény, amelyen belül a kínaiak küldtek öt ösztöndíjast Magyarországra, hogy ezek tanuljanak magyarul. Ennek fejében a magyarok is küldtek Kínába öt ösztöndíjast, hogy megtanuljanak kínaiul. Ez aztán évekig szélesedett, és ennek csak nyomában kullogott a tudományosság. 1958-ban jutottam ki először Kínába.

GI: És ott Kínában kikkel volt kapcsolatban a Tanár Úr?

CsB: Na most várjon. Kínában ez nem is történhetett másképpen, csak úgy hogy ekkor már régen túl voltam az ösztöndíjas koron, ekkor már egyetemi docens voltam vagy valami ilyesmi. Szóval a lényeg az, hogy kaptam egy akadémiai kiküldetést. Ezt Ligeti akadémikusnak köszönhetem, aki ekkor már a Tudományos Akadémia alelnöke lett. Ez is egy ilyen szerencsés véletlen, ami nyilván annak volt köszönhető, noha ő nem lépett be a pártba, hogy egyike volt azoknak a tekintélyes magyar tudósoknak, akik tudtak is oroszul, tehát meg lehetett választani az Akadémia alelnökének. Mert az elnök Rusznyák István, aki orvosprofesszor volt és kommunista, az nem tudott oroszul.

\section{Második beszélgetés}

\section{6. december 7. 10.40-13.00}

\section{Jelen vannak: Csongor Barnabás, Ferenczy Mária, Galambos Imre}

CsB: 1941 őszén Pröhle Vilmos nyugdíjba ment, és nem volt utóda, akit ki lehetett volna nevezni a Kelet-Ázsiai Tanszékre. A szokásos eset az lett volna, hogy ebben az időben a tanszék szünetel, tehát a könyvtárát raktárba teszik, helyiségét felszámolják addig, amíg egy új professzorábilis valaki 
nem jelenik meg a szakmában. Ligeti professzor, akit ugyanekkor neveztek ki, illetőleg hát léptettek elő nyilvános, rendes egyetemi tanárrá, és megcsinálták neki a Belső-Ázsiai Tanszéket, úgy találta, hogy ez nagy vesztesség lenne akár az ő stúdiumaira is, mert hiszen a belső-ázsiai stúdiumok eredményes folytatása sinológia nélkül bajosan képzelhető el. Ezért vállalta azt, ingyen, fizetés nélkül (már csak azért is, mert ha ezért díjazást kér, akkor ezt semmiféle hivatalos szerv nem fogja engedélyezni) vállalta ahogy abban az időben mondták - „társadalmi munkában” a saját tanszéke, a Belső-Ázsiai Tanszék mellett a Kelet-Ázsiai Tanszék vezetését is. Ez két dolgot jelentett. A legfontosabb az, hogy előadott a Kelet-Ázsiai Tanszéken, tehát kínai nyelvet és filológiát oktatott. A másik pedig az, hogy a Kelet-Ázsiai Tanszéknek maradt egy rovata a kari költségvetésben, szerényebb persze, mint a Belső-Ázsiáé, de azt jelentette, hogy könyveket és egyéb felszerelést, ami szükséges volt, lehetett vásárolni a tanszéknek. És lehetett kinevezni a tanszékre, ha arra méltó embereket találtak, tanársegédet, demonstrátort, hasonlót, egyebet az ott felnövekvő hallgatóságból.

Ez az állapot fent is lett tartva egészen 1950-ig, amikor is a felsőbb hatóság, mármint az akkori Művelődési és Felsőoktatási Minisztérium, túl soknak tartotta a Bölcsészkar tanszékeinek a számát, és elindult egy olyan törekvés, hogy egyszerübbé, áttekinthetőbbé alakítsák a Bölcsészkarnak a szerkezetét, ami azt jelenti, hogy lehetséges módon vonjanak össze tanszékeket. Most a tanszékek sokaságának egyik oka többek közt az is volt, hogy 1949-50 után nem egy tanszék, mint például a Német Tanszék, meg talán a magyar tanszékek, irodalmi tanszékek közül is valamelyik, vagy a Finnugor Tanszék mellé, a különben ott már '49 előtt müködő tanszékvezetők mellé kinevezték, illetőleg rehabilitálták az 1919-es idők hajdani professzorait, akiket 1919 után leváltottak, természetesen politikai okokból. Úgyhogy 1950 táján, amikor megért az idő arra, hogy ezek a rehabilitált professzorok nyugdíjba kerüljenek, a minisztérium felfigyelt arra, hogy Ligeti Lajosnak két tanszéke is van és feltette a kérdést, hogy vonják egybe a két tanszéket. Ligeti professzor ezen nagyon felháborodott és közölte, hogy nem azért tartotta fent ingyen és bérmentve, társadalmi munkában a Kelet-Ázsiai Tanszéket, hogy most megszüntessék. Erre az illetékesek azt felelték, hogy hát akkor viszont válasszuk ketté személyileg is. Így jutott eszükbe, hogy kinevezzenek engem a Kelet-Ázsiai Tanszék vezetésére. 
FM: Ez viszont 1963-ban volt.

CsB: '63-ban volt, bocsánat, persze. Olyan régen volt, hogy már nem emlékeztem rá. Igen. Nem '63-ban volt, hanem '61 vagy 62-ben, mert első feleségem akkor még élt. Arról már említés volt, hogy Ligeti Lajosnak, mint egyetemi tanárnak, tanszékvezetőnek nagy ambíciói voltak az utódok kinevelése dolgában. Ez történt a Belső-Ázsiai Tanszéken és ez történt a Kelet-Ázsiai Tanszék esetében is. Ennek a módja pedig az volt, hogy amellett, hogy a szokásos módon megtartott órái mellett a szemináriumait nagyon különleges módon használta fel, ugyanis a szemináriumokon a megadott témákat arra használta fel, hogy a részt vevő hallgatók által készített dolgozatok megvitatása során megtanítsa a hallgatókat a tudományos munkára, pontosabban a tudományos múvek megírásának, megfogalmazásának az útjára.

Az volt ebben a különleges, hogy Ligeti professzor ragaszkodott hozzá, hogy minden hallgatója, aki azzal az ambícióval jött az ő előadásait hallgatni, hogy valamikor valamelyik keleti tudományt múvelje, valamenynyinek valamennyi óráján jelen kellett lennie. Egyidőben emellett tartott még egy órát az általában érdeklődő hallgatók számára, ami, ha jól emlékszem, Belső-Ázsia történetével foglalkozott. De aztán később azt hiszem, ezt abba is hagyta, mert nyilván rájött arra, hogy felesleges fényüzés, révén hogy ezek közül az alatt az idő alatt nem került ki egy olyan sem, akiben aztán komolyabb érdeklődés mutatkozott az iránt, hogy valamelyik keleti stúdiumban elinduljon. És a szemináriumhoz tartozott természetesen az is, hogy a témákat, amiket a hallgatók feldolgoztak, nem szóban kellett előadni, hanem írásban kellett benyújtani, lehetőleg annyi példányban, ahány hallgató részt vett benne. Ezek száma maximum három vagy négy lehetett, mert egyszerre több hallgatója nemigen volt neki. És ennél fogva ezek a viták meglehetősen érdekesek és nagyon tanulságosak is voltak.

GI: Tegnap a Tanár Úr említette, hogy Ligeti annak idején Párizsban tanult. Erről van valami információ, lehet tudni, hogy ott hogyan s miként tanult?

CsB: Hát azt tudom, hogy akinek a nevét sokat emlegették, az Paul Pelliot volt, ${ }^{9}$ akit mesterének és tulajdonképpen alighanem eszményképének is tartott. Ö valóban egy nagyon széles tudású belső- és kelet-ázsiai filológus

9 Paul Pelliot (1878-1945), francia sinológus nyelvész, egyetemi tanár, a modern sinológia egyik legnagyobb hatású képviselője, kinek írásai legtöbb esetben ma sem veszítettek jelentőségükből. 
volt. A '30-as évek közepétől és végéig, azt hiszem, a T'oung Pao címü folyóirat szerkesztője is volt, és ebből az időből vannak például olyan T’oung Pao kötetek, amik tele voltak az ő általa írt recenziókkal, más müvek ismertetésével. És az ismertetések nem egy esetben olyan alaposak, hogy a recenzió megjelenése után a kollégák elő sem vették magát a müvet, hanem csak a recenziót olvasták el. Annyi tudós észrevétel és javítás és kiegészítés volt a recenzióban, hogy magát a müvet nem is volt érdemes elolvasni.

GI: És ebben az időben, amikor a Tanár Úr tanult, vagy közvetlenül az első időben, kik voltak még azok a külföldi tudósok vagy kutatók akik eszményképként szóba jöhettek? Vagy kik voltak egyáltalán azok, akikre felnéztek? Mert most említette a Tanár Úr Paul Pelliot-t, meg tegnap említette Karlgrent. Ki volt még, akinek a müveit komolyabban olvasták?

CsB: Tulajdonképpen annyira elfoglalt engem az a probléma, hogy a Ligeti akadémikus nagyon alapos tudású, de mégiscsak személyileg eléggé korlátozott terjedelmü és skálájú mértékben volt képes a sinológia tudományát mủvelni és tovább adni, annyira elfoglalt magának az egész sinológiának az áttekintése, és ugyanakkor viszont az európai világ nyugati felétől való elzártsága, hogy egyszerúen nem nyílt mód kitekintésre. A kitekintés csak 1960 után volt lehetséges. Valamikor 1945 után alakult Párizsban és Londonban az akkor induló fiatal nyugati sinológusok közül a Fiatal Sinológusok Konferenciája. Akire emlékszem és vezetők voltak, az a Herbert Franke, ${ }^{10}$ aztán a Ruhlmann (francia) ${ }^{11}$ és Zürcher (svájci).

GI: Az Erik Zürcher? ${ }^{12}$

CsB: Az az!

GI: És például Berthold Lauffer ${ }^{13}$ nem került sosem képbe?

CsB: De, a müveit olvastuk. Mondjuk a korlátozottság azt hiszem nagy mértékben annak tudható be, hogy hát maga Ligeti is, akinek számára a sinológia müvelése csak egy volt, és tulajdonképpen segédtudomány volt a saját szakmája kutatásának, a mongolisztikának, vagy ha jobban úgy tet-

10 Herbert Franke (1914-2011), német sinológus, a Jurchen és Mongol korszak történelmének jeles kutatója.

11 Robert Ruhlmann (1920-1984), francia sinológus, fő területe a kínai irodalom története.

12 Erik Zürcher (1928-2008), valójában holland sinológus, aki elsősorban a buddhizmus kínai kezdeteinek a kutatásával vált híressé.

13 Berthold Laufer (1874-1934), német születésű antropológus, aki 1904-től az Egyesült Államokban élt. Elsősorban kínai témájú munkákat írt, de pályája korai szakaszában voltak jelentős publikáció a mongolisztika és tibetológia területén is. 
szik, altajisztikának az elmélyítéséhez. Berthold Laufferrel kapcsolatban, ha jól emlékszem, egy dolgom volt. Ö írta a Sino-Iranica címü könyvet, ${ }^{14}$ abban volt neki egy nagyon érdekes müvelödéstörténeti sorozata, hogy a kínaiak nyugatról, iráni kultúrterületről és nyelvterületről milyen kultúrtermékeket vettek át vagy adtak át. Ezek között volt egy, ahol vitába kellett,

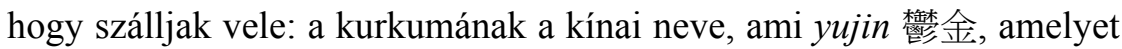
ö elvetett, mint nyugati eredetüt, révén hogy hangtörténetileg és nyelvileg nem látta azonosíthatónak a két hangot, az iráni, azt hiszem, gurkum, és a kínai yujin régi alakot. Én viszont egy dolgozatomban (hát nem egy dolgozat volt ez sem, csak egy lábjegyzet) bizonyítottam, hogy a yujin írásjegye bizonyos déli nyelvjárásokban nem vokálissal kezdődik, hanem g-vel. Tehát a kínai yujin igenis az iráni kurkumának a megfelelője, tehát a kínaiban a kurkuma neve iráni jövevény.

GI: És Karlgren munkásságához hogy viszonyult a Tanár Úr?

CsB: Ligeti abban az időben nagy szenvedéllyel vetette rá magát Karlgren müvére, Karlgren müvének a kritikájára. Maga is rávetette magát a kínai hangtörténetre, ehhez két későbbi kínai munkát vett elő. Egyik volt a Menggu ziyun 蒙古字韻, ami egy mongol-kori szótár, amelyben a kínai írásjegyek ejtése fonetikusan a mongol 'phags-pa írással volt írva. Ezt kezdte boncolgatni, bogozgatni és ebből bizonyos nyelvtörténeti, hangtörténeti tanulságokat levonni. A másik pedig a Hongwu zhengyun 洪武正韻, amelyik egy kínai-kínai szótár, mint a neve is mutatja, a Ming dinasztia első császárának idejéből való munka. Tulajdonképpen Ligeti akadémikus ezekkel a munkákkal kezdett foglalkozni és erről kezdett órákat tartani és előadni, ekkor kezdtem elfordulni a nyelvtörténettől egyszerüen abból az okból, hogy Ligeti akadémikus annyira beleásta magát ezekbe a problémákba, hogy érdekesebbnél érdekesebb, akkor lélegzetelállítónak érzett következtetéseket vont le bizonyos területekröl, amiktől hát szemem-szám elállt, mikor hallottam őket. Mármint Karlgren eredményeihez képest. De mindig hozzátette, hogy „Édes fiam, ezt én állapítottam meg, meg ne írja!” $\mathrm{Na}$ most hát ez egy akkora intellektuális frász volt, hogy így dolgozni valamivel, és így folytatni további kutatásokat, hogy olyan ismeretekkel rendelkezem, amiket a későbbi munkáimban nem szabad felhasználnom,

14 Berthold Laufer. 1919. Sino-Iranica: Chinese Contributions to the History of Civilization in Ancient Iran, with Special Reference to the History of Cultivated Plants and Products. Chicago. 
mert nem szabadna erről tudnom, ezt egyszerúen nem tudtam megcsinálni. Úgyhogy ekkor kezdődött az, hogy kezdtem elpártolni a nyelvtörténettől és egyéb indíttatások következtében kezdtem áttérni az irodalomtörténetre.

A nyelvtörténettel kapcsolatban viszont volt azért még két jelentös felfedezésem. Az egyik probléma abból állt, hogy az ujgur és tibeti írásos kínai nevekről és szavakról, amelyeknek a kutatásával foglalkoztam, azokról csakhamar kiderült, hogy nagyrészt a Tang-korra vagy a Tangkor végére mennek vissza. Ezt mutatja a hangállapotuk, $s$ abból lehetett különböző következtetéseket levonni. És ehhez volt például egy dolgozat, amit annak idején Luo Changpei ${ }^{15}$ tanár úr tett közzé angolul és kínaiul egy kötetben (megvan nekem is valahol) és abban szerepel egy csomó tibeti átírásos kínai szöveg. Ezeket fel is dolgoztam rendben, de a szövegek elején le van fényképmásolatban közölve a Qianziwen 千字文nek egy szövege, mellette az írásjegyek tibeti átírása. Ez nem is tudom, miért lett közölve, mert semmi különlegeset nem mutat. Egyetlen helyen van benne a $z h i$ 治 írásjegy, és amellett ott van a tibeti átírása, de a tibeti átírása az úgy fest, hogy li. Luo Changpei-nek érdemei vannak abban, hogy nekiállt a Karlgren munkásságának megjelenése után a dél-kínai nyelvjárásokat feldolgozni. Van egy monográfiája, azt hiszem, az Amoy nyelvjárásról, amiről kimutatja, hogy az nem vezethető le simán és egyszerüen azokból a rekonstrukciókból, amiket Karlgren megállapított a Qieyun 切韻 hetedik század eleji szótár hangállományából, s amit nem tud megmagyarázni.

$\mathrm{Na}$ most legjobb tudomásom szerint én jöttem rá, hogy ennek a furcsa aberrációnak mi az oka, révén hogy Karlgren rekonstrukciójában ez úgy hangoznék, hogy gji, egy velár j-vel és i-vel a végén. Luo Changpei próbálkozik déli nyelvjárásokkal, de maga is rájön arra, hogy ez nem megy. Nem tudom, hogy honnan támadt egy ötletem, de rájöttem arra, hogy ez az írásjegy szerepel egy Tang-kor elei császárnak a személynevében, akit úgy hívtak hogy Li Zhi 李治 (ur. 649-683). Mint szokásban volt, az uralkodó császár neve, ming-je, az tabunak számított, tehát Tang-kori munkákból, illetőleg a Tang-kor történetéből megállapítható, hogy a zhi 治 írásjegy tabu alá esett és a $z h i$ 治 írásjegyet mindenütt li-nek kellett olvasni. Csak

15 Luo Changpei 羅常培 (1899-1958), kínai nyelvész, a kínai nyelv történeti hangtanának kutatója. A kérdéses mủ az 1933-ban megjelent Tang Wudai xibei fangyin 唐五代西北 方音. 
mivel a kínai írás az olvasatot nem tükrözi, erre sehol semmiféle adat nem volt, csak ezen az egyetlen helyen, amire véletlenül bukkantam. És egy lábjegyzet lett belöle.

Másik ilyen nyelvtörténeti talált kincsem volt a ZDMG, a Zeitschrift der Deutsche Morgenländische Gesellschaft nevü folyóiratnakaz 1940-es kötetében, mégpedig az első számban szereplö, egy egyébként nagyon ritka brahmi írással átírt kínai szöveg. Ezt aztán szintén megírtam egy cikkben valahol, aztán 1960-ban vagy mikor elő is adtam egy konferencián. Erről kiderült, hogy ez egy buddhista szöveg töredéke, amiben szerepel a shan nanzi shan nüren 善男子善女人 összetétel, amelyben a brahmi írás alapján ki lehet mutatni, hogy a $z i$ 子 írásjegy ezeknek az összetételek olvasatában a magánhangzó rövidnek hangzik, amíg önálló formában a $z i$ 子 írásjegyben a magánhangzó hosszú. Tehát már ennek a szövegnek az átírásában tükröződik az a kínai nyelvi sajátosság, hogy ezeket az összetételeket folyamatosan olvasva az összetétel második tagjának az írásjegye az könnyü ejtésü (qingsheng 輕聲), tehát a zenei hangsúlyát elveszti. Szóval a shan nanzi shan nüren összetétel szerepel két vagy három ízben. Nem hosszú az egész szöveg.

Úgyhogy ezzel tulajdonképpen búcsút is vettem a hangtörténettöl. Persze ma már a sinológiának ez az ága, tehát a hangtörténet, azt hiszem, jóval fejlettebb. Szóval nekem is nagyon meg kéne erőltetnem magam, ha bele akarnék kezdeni vagy folytatni akarnám, de hát annak most már nem sok értelme lenne. Szerencsére azokat az ismereteket, amelyektől a Ligeti óvott, hogy felhasználjam a munkáimban, azokat szerencsésen el is felejtettem. Úgyhogy az a veszély valószínüleg nem fenyegetne.

GI: De a Ligeti megírta ezeket?

CsB: Nem. Ez volt a nagy probléma vele, hogy ő viszont annyira kritikus volt. Ligeti egyik jelmondata az volt, hogy „Gyerekek, ne higgyenek senkinek, legkevésbé saját maguknak!” Szóval rendkívül önkritikus és kritikus volt, aminek persze volt egy érdekes visszája is. Már érettebb koromban olvastatta velem nem egyszer a korrektúráit, egészen addig, amíg volt egy eset, amikor rájöttem arra, hogy a korrektúrában hiba van. Odadugtam lelkem teljes ártatlanságával az orra alá, hogy Professzor Úr, kérem, itten van valami. Megnézi a szöveget, adja ide, fiam, satöbbi, satöbbi, az nem úgy van... Soha többé nem adott nekem korrektúrát olvasni. Annyira szégyellte azt, vagy hogy mondjam, titkolni akarta, hogy ö ott egyszer valamit elvétett. 
$\mathrm{Na}$ de én elhagytam a nyelvészetet, $\mathrm{s}$ jött az irodalom. Kétfelől is indítást kaptam. Az egyik az, hogy akkor Európának hívták, azt hiszem, azt a kiadót, amelyik az idegennyelvü szépirodalom fordításaival foglalkozott. Felhívott engem egy egyetemista társam azzal, hogy nézz ide, kaptunk egy javaslatot arra, hogy Baj Csüjinek a csetverosztisje, ugye a négysoros verseit fordítsuk le magyarra. Hát lévén, hogy a Baj Csüji az egy kínai (hát az Po Csüji [Bai Juyi] 白居易 magyarul), hát gondoltuk, hogy mégiscsak jobb lenne eredeti kínaiból fordítani, nem pedig oroszból. Nota bene, akkor fordították Mao Cetung (Mao Zedong) müveit magyarra, természetesen nem kínaiból, hanem oroszból. Nagy megkönnyebbülésünkre, mert el tudom képzelni, hogy mekkora eszmei viták lettek volna arról, hogy mit jelent az illető kínai rész. Mert mi magyarok, pláne magyar sinológusok, akik hát valamit értettünk a marxizmusból, mégsem mi lettünk volna az a tekintély, akiknek a felső pártfórumok elhitték volna, hogy ez egy hiteles fordítás. Nota bene, talán emlékszik rá, hogy amikor a Kínai Népköztársaság felvette a kapcsolatot a Szovjetunióval, a szovjet kormánynyal, az első szovjet nagykövet, bizonyos Jugyin, ${ }^{16}$ a filozófiai tudományok doktora volt, mint utólag kiderült, azzal a be nem vallott céllal, hogy a sajtó alá rendezendő Mao Cetung összes múveit eszmei szempontból felülbírálja.

GI: Felülbírálja?

CsB: Megigazítsa. Ezt persze soha nem volt megmondva, de hát nyilvánvaló volt.

FM: És történt is, mert történetesen egy dolog volt, amit én összekerestem és egy magyar tanulmányban vagy szövegben úgy tudtam leírni, hogy az orosz szöveg az inkább magyarázata és kibontása a kínainak, mintsem fordítása.

CsB: Ezt a kínaiak is tudták, ugye, mert úgy emlegették a dolgot, hogy Makesi-Engesi-Mao Zedong sixiang 馬克思、恩格斯、毛澤東思想: Marx, Engels és Mao Cetung elmélete. Elég az hozzá, hogy ez volt az egyik indítás, hogy azt mondta a kiadó, hogy akkor fordítsuk a Po Csüjit kínaiból, ne oroszból. Hát nekem akkor még sejtelmem sem volt a kínai irodalomról, mert nem értem rá, hogy klasszikus irodalommal foglalkozzam. Viszont ott volt a polcomon egy kötet Po Csüji, amit egy meghalt

16 Pavel F. Jugyin (1899-1968) orosz filozófus és politikus, 1953-tól 1959-ig a Szovjetúnió kínai nagykövete. 
magyar sinológus hagyatékából vásároltunk a tanszéknek. Az illető egy középiskolai tanár volt, bizonyos Ágner Lajos, ${ }^{17}$ aki valamikor a huszadik század elején tanult - valószínűleg Németországban - kínai nyelvet, de valószínüleg tanult japánt és valószínüleg tanult koreait is, mert a könyvtára maradványait a lánya behozta a tanszékre. Nagyon gazdag könyvtára volt, úgyhogy háromfelé is oszlott belőle: a tanszéknek, a Kelet-Ázsiai Múzeumnak és az Akadémiai Könyvtárnak. A tanszéknek magának sikerült szereznem egy régi, de már európai kötésü Po Csüji kötetet.

Akkor jöttem rá (mert akkor fogalmam sem volt róla, hogy a klasszikus irodalom hogy néz ki, egyszerủen nem értem rá azzal foglalkozni), hogy Po Csüjinek bizony nemcsak négysoros versei vannak, hanem nyolcsorosak is, sőt annál hosszabbak is. Közöltem a kiadóval, hogy érdemesebb lenne egy válogatott Po Csüjit kiadni. A kiadó lelkesen kapott az egészen, nagy divatban volt és politikailag is fontosnak tartották a kínai művek magyarul kiadását. Lefordítottam kínai eredetiből egy csomó Po Csüji verset, négysorosat meg hosszabbat is, és megjelent egy kötet $P o$ Csüji válogatott versei címmel. Áldott szerencsénkre abban az időben, az ötvenes évek közepe táján, volt egy csomó nagyon jó magyar költő, Weöres Sándor, de akár még Szabó Lőrinc meg más is, akik akkor diszkréten szilenciumra voltak kitéve, saját verseik nem jelenhettek meg. Weöres Sándor gyerekverseket meg hasonlókat írt, és müfordításokat is. Szóval a magyar költők színe-java állt neki klasszikus kínai költőket magyarítani, ami hát egy óriási nyereség volt.

Akkor megindult egy olyan folyamat, amiben aztán egy akkori rövidesen végzett hallgatóm, Tőkei Ferenc (ha ismerős ez a név), is részt vett, sőt átvette az egésznek a vezetését is. Az ő közremüködésével sikerült létrehoznunk egy világirodalom-szerü sorozaton belül egy kétkötetes klaszszikus kínai költők antológiát. Az első kötetét Tőkei Ferenc szerkesztette, ez a kezdetektől, tehát a Dalok Könyvétöl a Sui-korig tart, a második kötet a Tang-kortól a tizenkilencedik századig, ezt én szerkesztettem.

GI: És a korábbi fordítások, például a Kosztolányié?

CsB: Na hát azok közül is vettünk be. Azok angolból-németből lettek fordítva, és egy csomó esetben nagyon jók. De az új fordítások is nagyon-nagyon jók voltak. Nyilván azért, mert azok a fordítások, amelyeknek az alapján

17 Ágner Lajos (1878-1949), irodalomtörténész, müfordító. Eredetileg a Berlini Egyetemen tanult kínai nyelvet. 
ők dolgoztak, azok lelkiismeretes fordítók és prózafordítások voltak, tehát a rímelés és prozódia kedvéért nem változtatták meg annyira a szavak jelentését, hogy feláldozták volna a mondanivalót. Csak annyira, amennyire a magyar költő vénája sugallta és engedte, de hát jó költő volt a kínai is, jó költő volt a magyar is, tehát ebből jó eredmények születtek.

Egy érdekes baki történt ezekben a müfordításokban. Az egyik ilyen versben van egy sor, amit aztán Illyés Gyula írja $A$ kínai szelence címü kötetében - mert elhatározta, hogy ő is kiad egy ilyen könyvet és ír hozzá egy írói előszót -; az előszóban leírja azt, hogy Kínában a gyász színe sárga. Honnan az ördögből vette ezt Illyés? Nézem, nézem, nézem, egyszer csak rátalálok, hogy van kínai vers, amit lefordít (nem is ö, hanem még Kosztolányi), és a verssor így szól, hogy „a halál sárga tavasza”. Mi az ördög ez a halál sárga tavasza? Megnézem az eredetit, hát kiderült, hogy a „sárga tavasz” szó úgy szól, hogy yellow spring. Hát a spring az angolul „tavasz”, de „forrás” is. És a yellow spring az közhely Kínában: a halál sírja, a sárga sír, a sárga föld. Vagyis a halál. Erről aztán későbbi tanítványunk, bizonyos Csibra Zsuzsa, aki még ma is müködik és nagyon jól és érzékenyen és szellemesen foglalkozik a klasszikus kínai költészettel, mutatja ki ezt, meg még mutat ki más egyéb ilyen dolgokat a korai fordításokkal kapcsolatban. Na ez volt az egyik forrás, hogy nekiálltunk klaszszikusokat fordítani a Tőkei Tanár Úrral, aki ekkor már tanár volt.

Tőkei Ferenc valóban egy korszakos jelenség volt nem csak a magyar, de a nemzetközi sinológiában is. Valamikor az ötvenes évek végén (vagy közepén? nem tudom már) megjelenik egy gyönyörü Lavalliere nyakkendős fiatalember, amelyikben ilyen csokorba szedett világoskék-fehér petytyes csokornyakkendő volt, és közli, hogy meg kell reformálni az európai drámát, s ezért akar ő kínait tanulni. Ez volt a Tőkei Ferenc. A Pesti Piaristáknál végzett, pocsék rossz tanuló volt, de tekintve hogy minden évben ő írta meg a darabot az iskolai előadásra, mindig átengedték. Bekerült a sinológiára. Hát először is kiderült, hogy egy nagyon jó fej. Keveset mondok, ha annyit mondok, hogy zseni. Aztán kiderült, hogy abbahagyta a drámával való foglalkozást, nem is írt több drámát, hanem rávetette magát az esztétikára, azon belül a kínai költészet esztétikájára. Azzal kapcsolatban írta a Kinai elégia születése címü munkáját, aztán Miklós Pállal közösen (aki egy fiatal kollegám, aki Kínában tanult kínait, de idehaza müvészettörténetet és irodalmat, és amellett ő maga is müvészlélek volt) 
ketten írtak egy kínai irodalomtörténetet. Tőkei írt a régi irodalomról, Miklós Pál a modern kínai irodalomról.

Esztétikából Tőkeinek még ott van a Wenxin diaolong 文心雕龍 elemzése, aminek szintén nagyon kevés nyugati tudós állt neki. A Wenxin diaolong az Az irodalom szive és sárkányfaragás címú esztétikai munka, piszok kemény, elméleti szöveg. Ezek közül aztán a Kinai elégia születése megjelent idegen nyelven, franciául és japánul is.

FM: És akkor ott volt még a disszertációja, ami megint egy másik terület, a Zhou-kori szociális viszonyokról.

CsB: Igen, tulajdonképpen belekontárkodott - hát nem kontárkodott, hanem éppen ellenkezőleg.

Elővette a történelmi materializmusnak a társadalmi formációk fejlödése címü elméletét és elővette a Marx szövegeket, azokat is, amelyek Marx életében nyomtatásban nem jelentek meg. A németek, illetőleg a moszkvai Marx-Engels-Lenin Intézet kiadta egy ilyen vastag kötetben a kéziratban maradt Marx-Engels müveket, amelyekböl kiderült, hogy nagyon fontos és megszívlelendő megállapítások találhatók egyáltalán az emberiség történetére vonatkozólag. Tökei nekiállt és helyretette azt a kategóriát, amelyik Marxnál azt hiszem csak úgy mellékesen szerepelt, hogy az „ázsiai formáció”. A hivatalos szovjet vezetés által hitelesített és hirdetett és eröltetett történeti fejlödés (ugye az ősközösség, a rabszolgatartás, feudalizmus, kapitalizmus) mechanikus ismételgetését tulajdonképpen félretolja, nem is tartja érdemesnek arra, hogy foglalkozzék vele. Ehelyett megállapítja, hogy a kínai fejlődés egy egészen más út és nem ebbe a menetirányba vezet. Nem mennék bele a taglalásába most, ehhez tulajdonképpen el kell olvasni a Feri múveit.

Visszatérve a saját indíttatásaimra, az első volt a Po Csüji, a második pedig a Vizparti történet, a Shuihu zhuan 水滸傳. Ez akkor már megjelent magyarul, egy rövidített német fordítás alapján Goda Géza (az idősebbik Goda) tollából. Mint annyi más klasszikus kínai regény Franz Kuhn német fordítása alapján készült. Ebből lefordították a Szép asszonyok egy gazdag házbant, meg lefordították a Vörös szoba álmát, meg azt hiszem, még más müveket is. A Vizparti történetnek viszont én álltam neki, hogy lefordítom magyarra a Goda Géza fordítása után eredeti kínaiból, mégpedig az akkor Kínában propagált és nagy mértékben terjesztett 71 fejezetes kiadás alapján. Mint ismeretes, a kínaiak (a kínai párt és kulturális vezető gárda) ezt a mủvet a kínai parasztforradalmak eposzának deklarálta, nem lévén tu- 
datában annak, hogy a parasztforradalom az egy önmagában ellentétes összetétel. Egyik kizárja a másikat.

Én viszont nagy gusztussal nekiláttam a lefordításának, nagyon-nagyon élveztem, és amikor a végére jutottam, akkor kezdtem el gondolkodni. Már annak az alapján is, amit fel tudtam addigra szedegetni a marxizmus elméletéből, a történelmi materializmus elméletéböl, nem utolsó sorban a Tőkei ihletésére és felhasználva azt a körülményt, ami tulajdonképpen tálcán kínálta magát, hogy a Vizzarti történet 108 höse mind úgy van bemutatva, hogy mindegyik esetében közölve van az, hogy mi a neve, mi a születési helye, és mit csinál, mi a foglalkozása, mi a szakmája. Meglepetéssel kellett megállapítanom, hogy a 108 szereplő közül egyik sem képviseli a hagyományos kínai társadalom két alapvető osztályát, magyarul nincs köztük se mandarin, se paraszt. Hanem mind a kettő közt létező, mozgékony társadalmi erők állnak, társadalmon kívüli elemektől kezdve egészen különböző szabadfoglalkozású elemekig. Ezt aztán megírtam egy cikkben, aminek az utolsó példányát odaajándékoztam egy pár éve itt járt ifjú (nálam fiatalabb) sinológusnak, akinek tartoztam vele. De megjelent angolul az Acta Orientaliabanaz „On the Popularity of the Shui-hu-chuan” (A Shuihu zhuan népszerüségéról) címü cikkemben.

GI: Én emlékszem, hogy a Shuihu zhuan a Világirodalom klasszikusai sorozatban jelent meg, valami kétszázezres példányszámban, ugye?

CsB: Igen. Két kiadásban is. Elöször a '71-es népköztársasági kiadás alapján, ami a Jin Shengtan-féle rövid kiadás, ${ }^{18}$ de - hogy mondjam - megforradalmasítva, tehát ahol Jin Shengtan 金聖嘆 letompította a dolognak a lázadó élét, ott forradalmasítva vagy forradalmárosítva. És aztán később már a Világirodalom klasszikusaiban három kötetben, amiben most már közölve lett mind a száz fejezet. Ott persze a 71-en túl teljesen csak a 100-ik fejezet lett lefordítva, 71-töl a 99-ig csak kivonatban. Ezt tulajdonképpen nem is lett volna érdemes csak kivonatban fordítani, nem is egy szerzőnek a müvei, satöbbi.

FM: Én valami százharmincezres példányszámra emlékszem, de majd utánanézek.

18 A hivatkozás a mű Jin Shengtan (ca. 1608-1661) által összeállított 70-fejezetes változatára vonatkozik. Tudtommal ennek a változatnak nem volt 1971-es kiadása, így talán az évszám nem helyes. 
GI: Csak én mintha régen, vagy húsz éve néztem volna és akkor ledöbbentem, hogy akkoriban milyen példányszámok voltak.

CsB: Hát jelen pillanatban itt tartok, azt hiszem.

GI: Még megkérdezném, hogy a sinológia jövőjét hogyan látja a Tanár Úr. Vagy akár a jelenjét is.

CsB: Borzasztóan sajnálom, hogy az életem vége felé járok, tudniillik az emberiség történetében soha nem volt szakasz következik, amikor világméretekben az európai kultúra és a kínai kultúra (és csak úgy mellesleg hozzávéve még az indiait) találkozása, igazi találkozása és egymás vívmányainak egymás számára való átadása következik. Ami nyilvánvalóan nagyon mozgalmas, nagyon változatos, időnként viszontagságos, de rendkívül érdekes korszaka lesz az emberiség történetének. Ha túléljük.

GI: És ezen belül Kínát hogy látja a Tanár Úr?

CsB: Nekünk európaiaknak, a Nyugatnak még nagyon sok mindent kell Kínától tanulnunk. A kínaiaknak pedig, ha egyáltalán lehet kívülről tanulságot adni, az az, hogy vessék le a sértettségüket és - hogy mondjam - kisebbrendüségi érzéseiket a Nyugattal kapcsolatban, mert hiszen ha összemérik is a Nyugat-Európa technikai fejlettségét, amelyet elöször az Ópiumháború ágyúival bizonyítottak be, ne tévesszék össze a kulturális fejlettséggel. Hanem mind a két oldal próbálja megkeresni azokat a pontokat, ahol közösen kezet tudnak nyújtani egymásnak. Persze ez így elméletileg elképzelve nagyon szépen hangzik, de egyszerüen egy meglehetősen elvont vágyálom, és hogy hogyan konkretizálható, azt bizony lehetetlen megmondani.

GI: Hát akkor köszönöm szépen az interjút.

CsB: Nagyon szívesen. Sajnos jelen állapotomban ennyi tellett tőlem.

GI: Nem, ez is nagyon érdekes volt. Köszönöm.

CsB: Nagyon szívesen. 